\title{
GEOMORPHOLOGICAL EVOLUTION OF THE COASTAL PLAINS IN THE HOLOCENE
}

https://doi.org/10.4215/rm2020.e19010

\author{
Kleber Carvalho Lima ${ }^{a^{*}}$ - Archimedes Perez Filho b
}

(a) Dr. in Geography. Professor at São Paulo State University (UNESP), Rio Claro (SP), Brazil.

ORCID: https://orcid.org/0000-0002-9468-2473. LATTES: http://lattes.cnpq.br/6828126996794621.

(b) Dr. in Geography. Professor at the State University of Campinas (UNICAMP), Campinas (SP), Brazil.

ORCID: https://orcid.org/0000-0001-6675-3740. LATTES: http://lattes.cnpq.br/4244941712717032.

\author{
Article history: \\ Received 01 October, 2019 \\ Accepted 15 March, 2020 \\ Publisher 15 May, 2020
}

(*) CORRESPONDING AUTHOR

Address: UNESP, Avenida 24 A, 1515, Bela Vista, CEP: 13506-900, Rio Claro (SP),

Brasil. Telefone: (+55 19) 3526.9331

E-mail: klebercarvalho.two@gmail.com

\section{Abstract}

The last eleven thousand years have been marked by several environmental changes in coastal regions and in Brazil, evolutionary models and sea-level variation curves indicated a general phase of marine regression, interspersed with peaks of transgression. These oscillations contributed to the evolution of extensive coastal plains. However, in the smaller coastal plains, these issues need more discussions. In the case study of the Itapicuru coastal plain, north coast of Bahia State, we aimed to complement the paleoenvironmental information to define the possible geomorphological evolution scenario during the Upper-Middle Holocene. We analyzed marine terraces and floodplain using particle size distribution, quartz grain morphological analysis, and OSL. The data indicates a slow and gradual regressive phase between 5 kyrs - 0,8 kyrs BP, responsible for the highest marine terrace's formation. Between $0.8 \mathrm{ka}$ A.P. and the Present, there was a fast and abrupt regression also observed in other places of the Bahia coast, with the formation of low terraces. We suggest that short-lived events may have been responsible for the evolution of other Brazilian coastal plains with similar characteristics.

Keywords: Coastal Geomorphology; Quaternary; OSL; Marine Terraces; Itapicuru.

\section{Resumo / Resumen}

\section{EVOLUÇão GEOMORFOLÓGICA DE PLANÍCIES COSTEIRAS NO HOLOCENO}

Os últimos onze mil anos foram marcados por diversas alterações ambientais nas regiões costeiras, sendo que, no Brasil, modelos evolutivos e curvas de variação do nível do mar indicaram uma fase geral de regressão marinha, intercalada por picos de transgressão, que contribuíram para a evolução de extensas planícies costeiras. Entretanto, nas planícies costeiras de menor dimensão, essas questões ainda carecem de maiores discussões. No estudo de caso da planície costeira do Itapicuru, norte da Bahia, essa pesquisa objetivou complementar as informações paleoambientais da área, com o propósito de estabelecer o possível cenário de evolução geomorfológica no Holoceno Médio-Superior. Foram analisados sedimentos de terraços marinhos e planície aluvial por meio de granulometria, morfologia e morfoscopia de grãos de quartzo e LOE. A correlação dos dados indicou fase regressiva lenta e gradual entre 5 e 0,8 ka A.P., com formação de altos terraços marinhos. Entre 0,8 ka A.P. e o Presente, houve regressão rápida e brusca, também observada em outros pontos do litoral baiano, com a formação de baixos terraços. Acredita-se que eventos de curta duração podem ter sido responsáveis pela evolução de outras planícies costeiras brasileiras com características semelhantes.

Palavras-chave: Geomorfologia costeira; Quaternário; LOE; Terraços marinhos; Itapicuru.

\section{EVOLUCIÓN GEOMORFOLÓGICA DE LLANURAS COSTERAS EN EL HOLOCENO}

Los últimos once mil años han estado marcados por cambios ambientales en las regiones costeras. En Brasil, los modelos evolutivos y las curvas de variación del nivel del mar indicaron una fase general de regresión marina, intercalada con picos de transgresión. Estas oscilaciones contribuyeron a la evolución de extensas llanuras costeras. Sin embargo, en las llanuras costeras más pequeñas, estos problemas necesitan más discusiones. En el estudio de caso de la llanura costera de Itapicuru, se objetivó complementar la información paleoambiental para definir el posible escenario de evolución geomorfológica durante el Holoceno Medio-Superior. Fueran analizados los sedimentos superficiales de terrazas marinas y llanuras de inundación utilizando la distribución del tamaño de partícula, el análisis morfológico de los granos de cuarzo y la LOE. La correlación de los datos indicó una fase regresiva lenta y gradual entre 5 y $0,8 \mathrm{ka}$ AP con formación de altas terrazas marinas. Entre 0,8 ka y el Presente ocurrió una fase regresiva rápida y abrupta, también observada en otros puntos de la costa de Bahía, con formación de bajas terrazas. Se cree que los eventos de corta duración pueden haber sido responsables de la evolución de otras llanuras costeras brasileñas con características similares.

Palabras-clave: Geomorfología Costera; Cuaternário; LOE; Terrazas Marinas; Itapicuru. 


\section{INTRODUCTION}

Brazil's coastline is the longest in Latin America, it is about 7,367 km (IBGE, 2011), long and has a wide geological, geomorphological and oceanographic diversity, under conditions of tectonic stability. Due to this variety, different proposals on how the coast should be compartmentalized have been put forward. One of the most well-known partitions was developed by Silveira (1964), who divided the Brazilian coastline into five main sectors, namely, the North, Northeast, East, Southeast, and South coasts. In these areas, several evolutionary models have been developed on coastal plains with similar characteristics (MARTIN et al., 1980; LESSA et al., 2000; TOMAZELLI and VILLWOCK, 1996; DILLENBURG et al.; 2000; DOMINGUEZ et al., 1990; MARTIN et al., 1996; GUEDES, 2009).

The eastern sector is the longest since it extends from the north of the State of Rio de Janeiro to the State of Bahia and is characterized by the presence of coastal plains in progradation. An evolution model was developed for this segment (DOMINGUEZ, BITTENCOURT, MARTIN, 1981) based on eight phases of marine regression and transgression, driven by wet and dry climatic phases (BITTENCOURT et al., 1979; MARTIN et al., 1979). According to this model, eustatic processes were the main factors responsible for the development and evolution of the coastal plains located in this part of the coast, exemplified by the plains of the Jequitinhonha, Doce and Paraíba do Sul rivers.

However, advances in research techniques and the expansion of research in specific coastal areas have produced new knowledge and led models to be revised (ÂNGULO and LESSA, 1997; LIMA et al., 2014)). Nevertheless, Dominguez, Bittencourt, and Martin's (1981) model of the eastern coastal sector is still considered a valid explanation of smaller coastal plains.

The MSL variation curves elaborated for various points along the Brazilian coast, including Salvador, Santos, Cananéia, Paranaguá, Itajaí-Laguna, Rio Grande do Norte, and Pernambuco have also contributed to the understanding of coastal evolution in Brazil (MARTIN et al., 1979; SUGUIO, MARTIN, FLEXOR, 1980; ÂNGULO and LESSA, 1997; BEZERRA, BARRETO, SUGUIO, 2003; SUGUIO et al., 2013).

Suguio et al. (1985) used eight MSL variation curves to conclude that, in general, the Brazilian coast between the States of Bahia and Santa Catarina, was submerged during the last 7 - 6,5 kyrs BP During this period, there were transgressive episodes when the sea level was about five meters above the current level, as well as regressive episodes. Although there are small differences in the shape and amplitude of the curves, it is agreed that in the last 2,5-2 kyrs BP there has been a generalized regression in the sea level, contributing to the progradation of the coastline in several sectors of the Brazilian shoreline (MARTIN, DOMINGUEZ, BITTENCOURT, 2003).

Bittencourt et al. (1979) identified three quaternary transgressions in the State of Bahia. The oldest transgression occurred at the level of the cliffs carved into the Barreiras Group sediments. The penultimate transgression occurred about $120 \mathrm{kyrs}$ BP and was responsible for the creation of marine terraces at an altitude of six to ten meters. The last transgression, about 5-5,2 kyrs BP, formed marine terraces at about four meters in altitude (BITTENCOURT et al., 1979; MARTIN et al., 1980).

The MSL variation curve developed by Martin et al. (1979) showed that during the quaternary marine fluctuations of the last 7 kyrs BP, which occurred north of Salvador city, the sea level reached three higher levels than the current one. In the last 2 kyrs BP, there has been a slow and gradual marine regression. Gonçalves (2016) reviewed the Salvador curve based on the radiocarbon dating of coral reef cores from the beaches of Guarajuba, Itacimirim, and Forte (figure 1). The author only found two higher sea levels with a slow regression between $4 \mathrm{k}$ and $0,8 \mathrm{kyrs} \mathrm{BP}$ and a rapid regression between $0,8 \mathrm{kyrs}$ BP until the current average sea level was reached.

Research carried out on the coastal plain of the Itapicuru River, north of Salvador city (figure 1), indicated the occurrence of local marine regression processes during the Holocene, up to 2,9 kyrs BP (ESQUIVEL, 2006; SANTANA, 2007; COSTA JUNIOR, 2008). However, it is uncertain whether the process has continued over 2,5 yrs BP, therefore there is a gap in our knowledge of more recent events in this area.

Consequently, this research aims to establish chronological relationships between surface deposits of marine terraces with other MSL paleoenvironmental indicators on the Itapicuru River coastal plain to complete the information on the Holocene at the local level. Determining possible geomorphological 
scenario may contribute to the understanding of similar coastal plains along the Brazilian coast, in the light of the latest paleo landforms indicators and dating techniques.

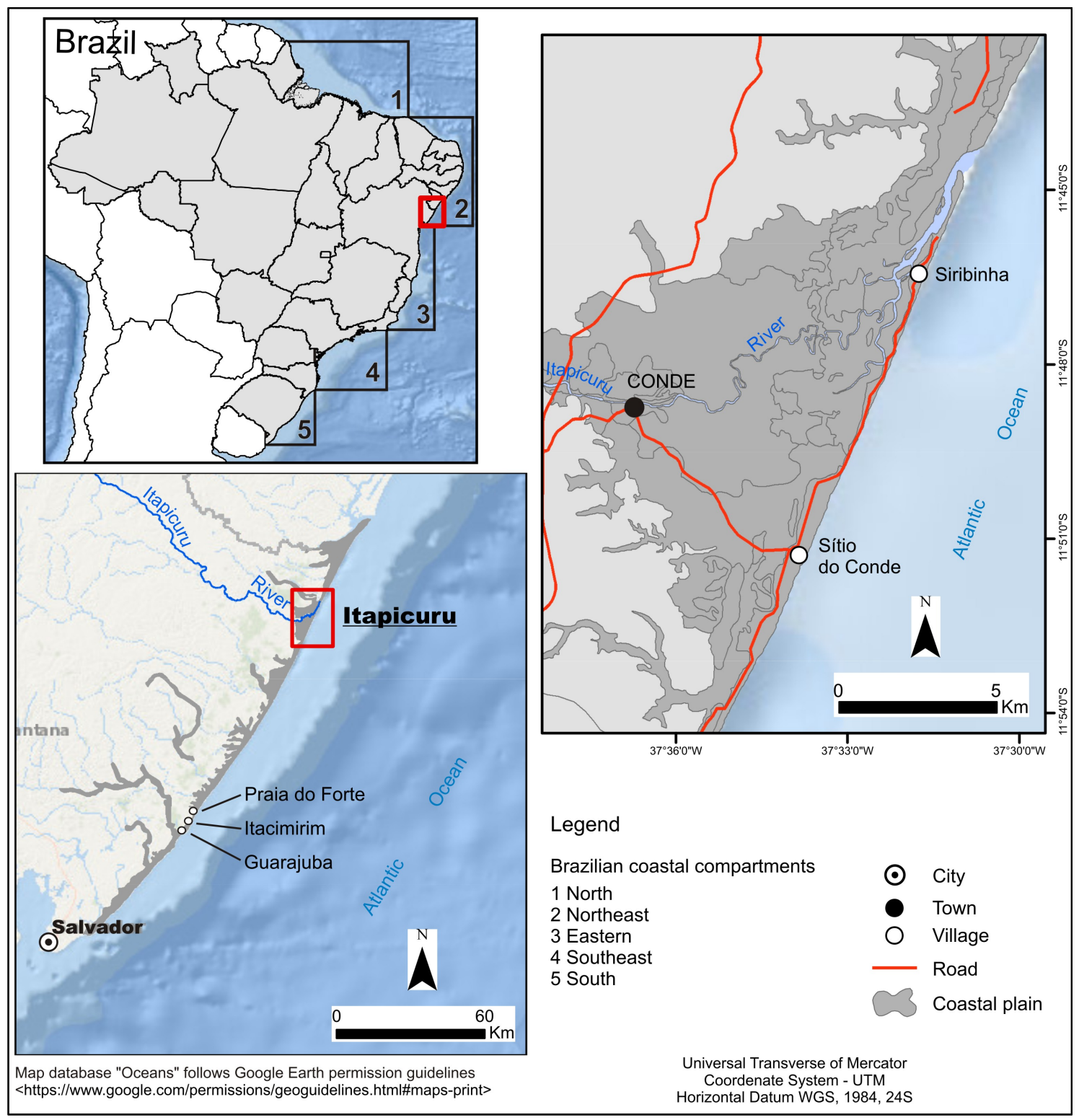

Figure 1 - Location map of the Itapicuru Coastal Plain.

\section{PREVIOUS RESEARCH}

Bittencourt et al. (1979) and Martin et al. (1980) explained the genesis of the Itapicuru coastal plain using general models developed for the coast of Bahia and subsequently, through the evolutionary model developed by Dominguez, Bittencourt, and Martin (1981). Esquivel (2006) reconstructed the local paleogeography based on the eight evolutionary stages that occurred between the Miocene-Pleistocene transition and the mid-Holocene. According to the author, stages I to $\mathrm{V}$ of the evolution of the coastal plain happened during the Miocene - Pleistocene and stages VI to VIII occurred during the Holocene. Santana (2007) proved the existence of offshore stages during the Holocene by shell midden deposit dating aged between 5,000 and 2,900 years BP.

Costa Junior (2008) dated Spodosol material in alluvial fans located in the contact area between Barreiras Group tableland and the coastal plain. The alluvial fans developed during the marine regression phases between 9,000 and 5,000 years BP. This research identified a slow and gradual 
regressive phase between 5,000 and 2,900 years BP, raising the hypothesis that the process has continued to the Present without alterations in the regressive rhythm.

Concerning recent fluvial processes, Farias (2014) calculated the sedimentation rate of the subtidal zone in the coastal plain of Itapicuru and found an annual rate of $5.4 \mathrm{~mm} / \mathrm{year}$ from 1994 and predicted the area's sedimentation in approximately 558 years, thus indicating the river's current contribution to the evolution of the coastal plain.

\section{REGIONAL FEATURES}

The coastal plain is associated with the mouth of the Itapicuru River, located between the current coastline and the Pre-Coastal Tableland, developed on material from the Barreiras Group. It has a typical humid tropical climate, with an annual average temperature of $24.7^{\circ} \mathrm{C}$ and an average rainfall of $1,422 \mathrm{~mm} /$ year, with a period of heavier rainfall between April and July (SEI, 1999).

The lithological units include predominantly quaternary material, composed of sandy, clayey and silty deposits (MARTIN et al., 1980). Neotectonic features are common in the Barreiras Group sediments, near the city of Conde (VILAS BOAS, SAMPAIO. PEREIRA, 2001; LIMA, 2010), such as liquefaction structures in conglomerates and fluidized structures, syncline and anticline folds, normal faults and tectonic joints with a preferential NW-SE direction (figure 3), which significantly contribute to slope evolution (DANTAS and LIMA, 2008; LIMA, 2010).

Relief forms of marine, wind, fluvial and lacustrine origin developed in the coastal plain. These include flood plains, river terraces, lacustrine alluvial plains, marine fluvial plains, marine terraces, and dunes. In the transition zone between the tablelands and the coastal plain, alluvial fans occur at the edge of paleo cliffs (figure 2).

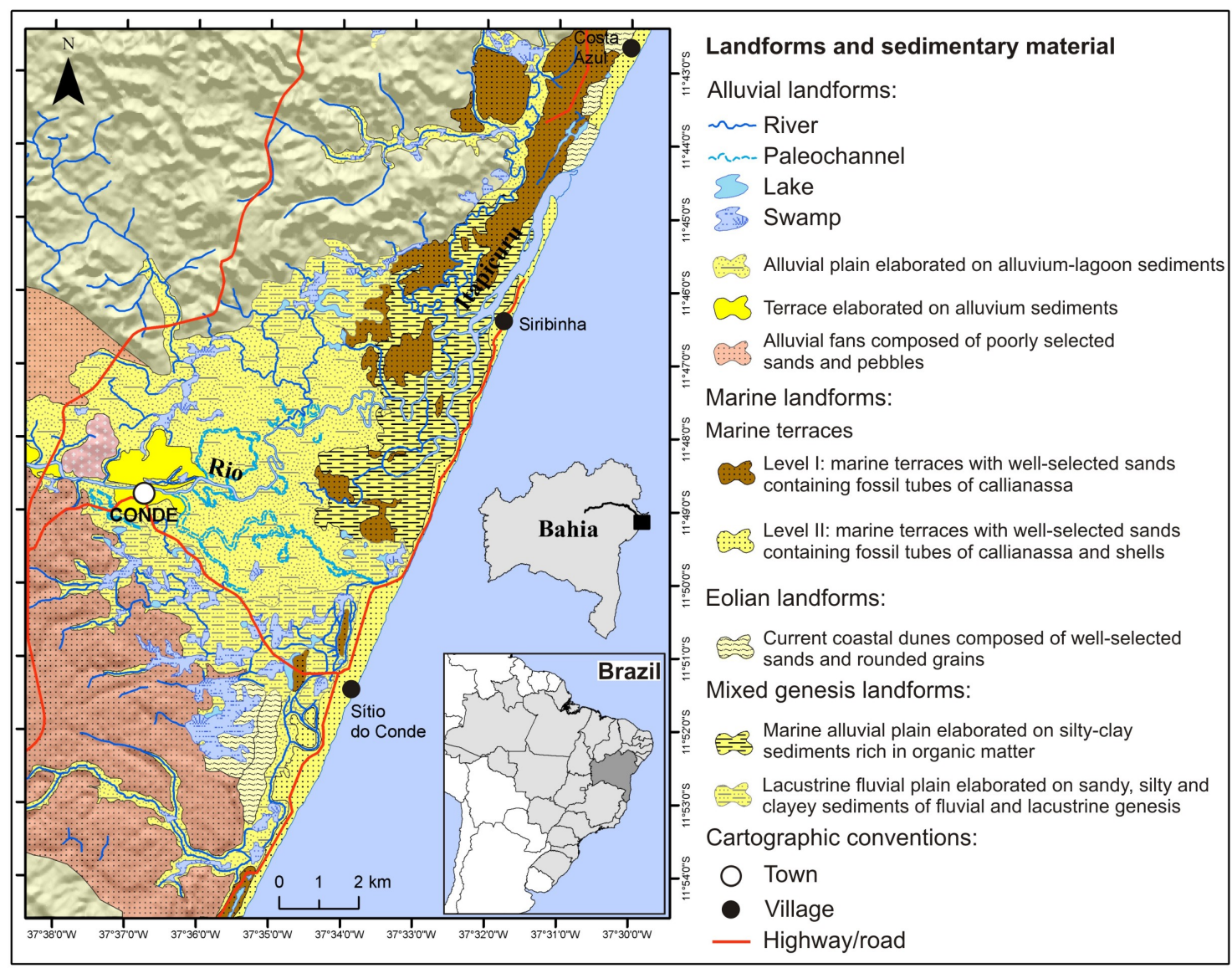

Figure 2 - Geomorphological map of the Itapicuru coastal plain. 

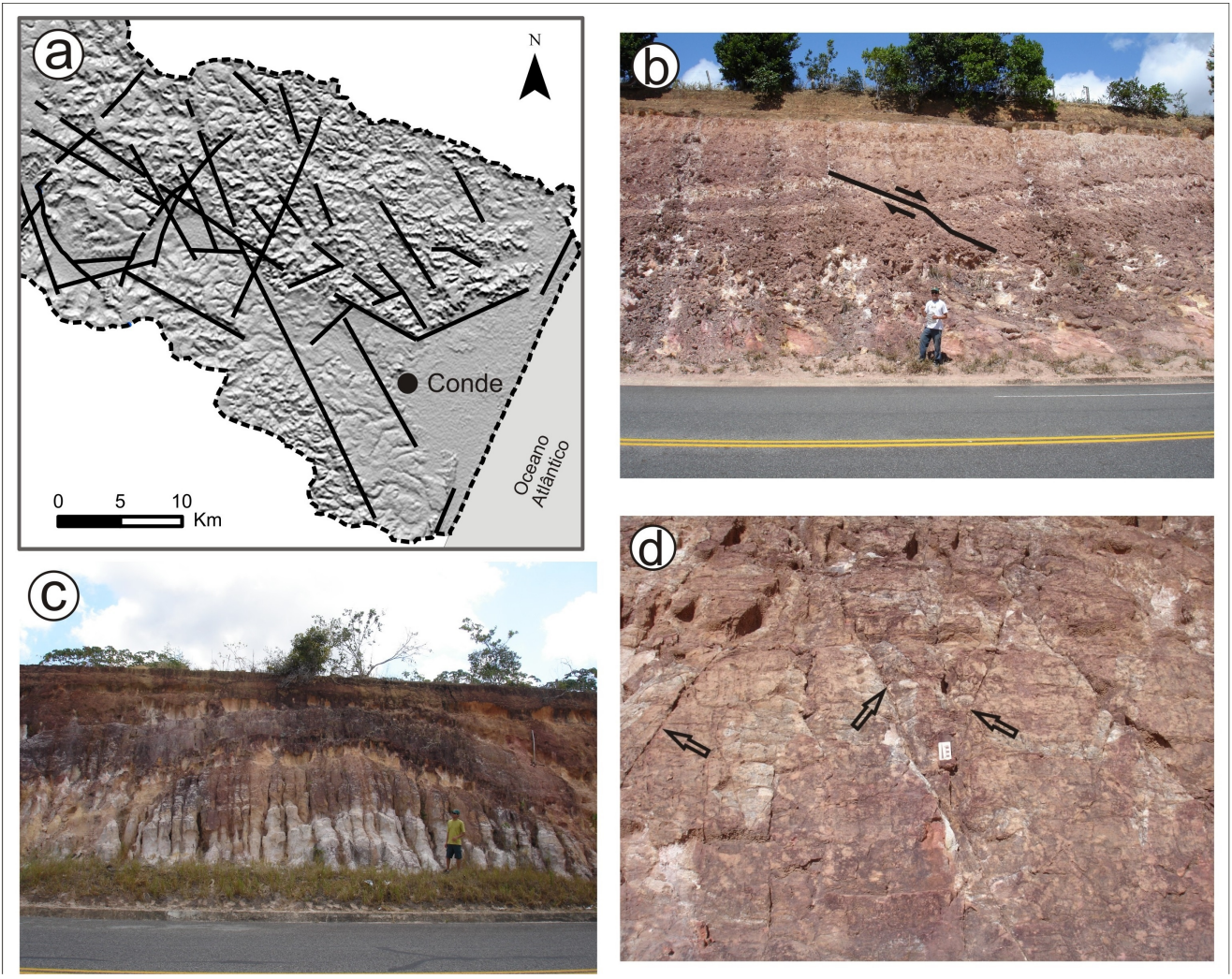

Figure 3 - Neotectonic features in the Barreiras Group sediments, near Conde: main structural lines in the low course of the Itapicuru (a); low-angle normal failure (b); anticline (c); and tectonic joints (d). Source: adapted from Dantas and Lima (2008).

\section{MARINE TERRACES}

According to Esquivel (2006), the marine terraces of the Itapicuru coastal plain were deposited at two distinct times. The first deposition occurred during the progradation of the local coastline after the peak of the Penultimate Transgression (BITTENCOURT et al, 1979), approximately 120,000 years BP. The second moment of deposition happened during the marine regression after the peak of the Last Transgression in approximately 5,100 years BP (BITTENCOURT et al., 1979; ESQUIVEL, 2006). The Pleistocene terraces are composed of well-selected, white quartz sands and the granulometry ranges from fine sand to medium sand and includes Callianassa fossil tubes (MARTIN et al., 1980).

There are blowout dunes on some sections of the surface of the Pleistocene terraces, resulting from the reworking of the terraces' surface by wind action. The Holocene terraces are comprised of deposits of well-selected, ocher-yellow quartz sand, seashells and Callianassa fossil tubes (MARTIN et al., 1980). There are foredunes (dune ridges) on the Holocene terraces, resulting from the wind's reworking of sediments on the beach face (ESQUIVEL, 2006).

\section{MATERIALS AND METHODS}

\section{FIELDWORK}

Based on the geomorphological map (LIMA, 2017), levels of the marine terrace located on the left and right banks of the Itapicuru River were selected to chronologically correlate terrace fragments with the same topographic level, which had lost spatial continuity after dissection by fluvial action. Thus, samples were taken of surface materials in two areas in marine terrace I and two areas in marine terrace II (figure 4). Two areas were also selected in the alluvial plain, to better understand recent river 
processes (figure 4).

Altogether, six one-meter-deep profiles were created and described. Samples for the granulometric and morphological analysis of quartz grains were taken at depths of 0-20 cm and 80-100 $\mathrm{cm}$ in the marine terraces. On the alluvial plain, 0-20 cm deep samples were taken and in units with different granulometric characteristics. Five samples from each profile were taken for absolute dating by Optically Stimulated Luminescence (OSL) at 70 and $80 \mathrm{~cm}$ depth, with the aid of opaque PVC tubes 60 $\mathrm{cm}$ long and $6 \mathrm{~cm}$ in diameter. The tubes were buried horizontally by percussion (figure 5), closed with caps and packed in black bags to avoid exposure to sunlight (SUGUIO, HEIFER, BARRETO, 2011).

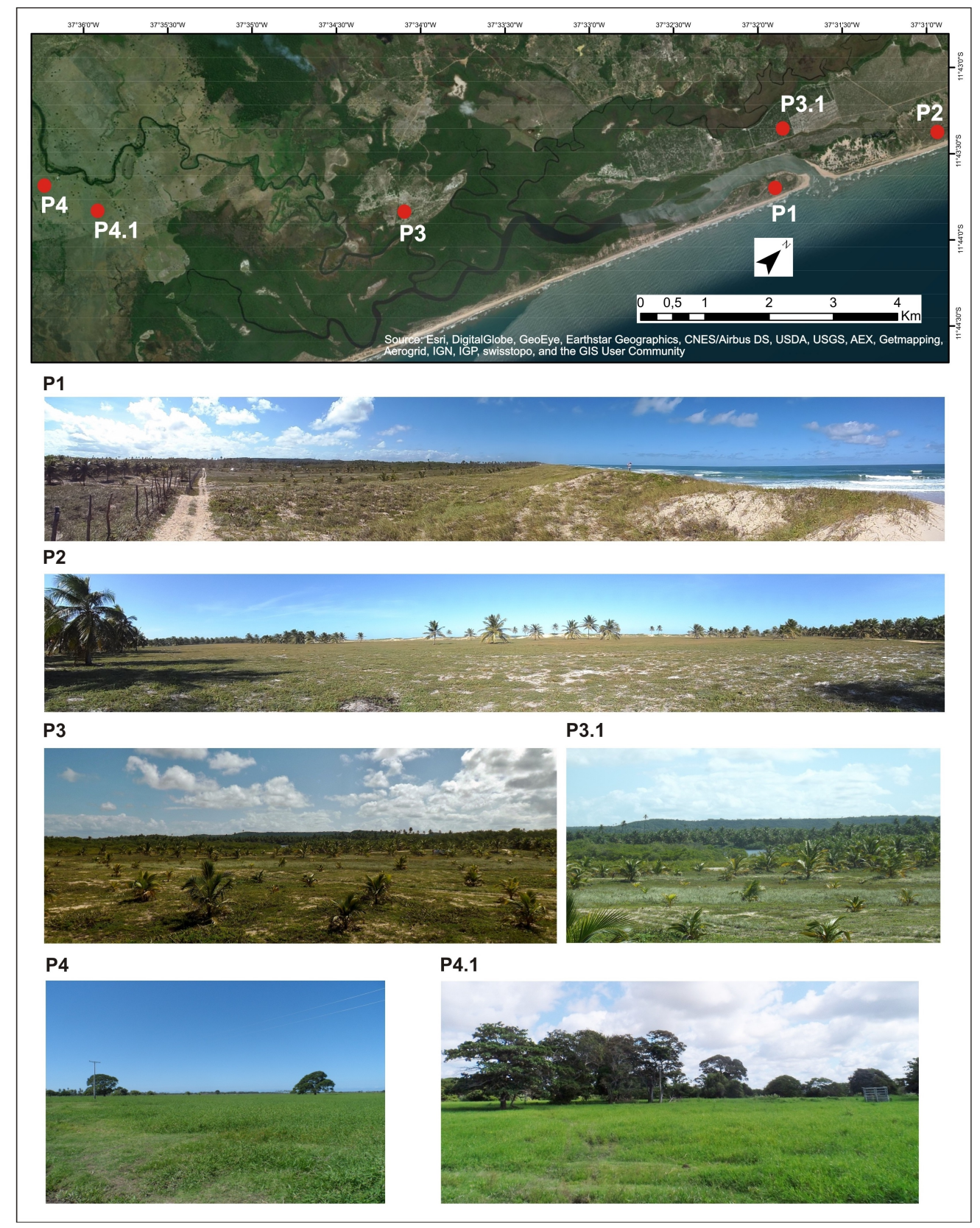

Figure 4 - Sampling points for surface deposits on the Itapicuru coastal plain. Holocene marine terraces (P1 and P2), Pleistocene marine terraces (P3 and P3.1) and floodplain (P4 and P4.1). 


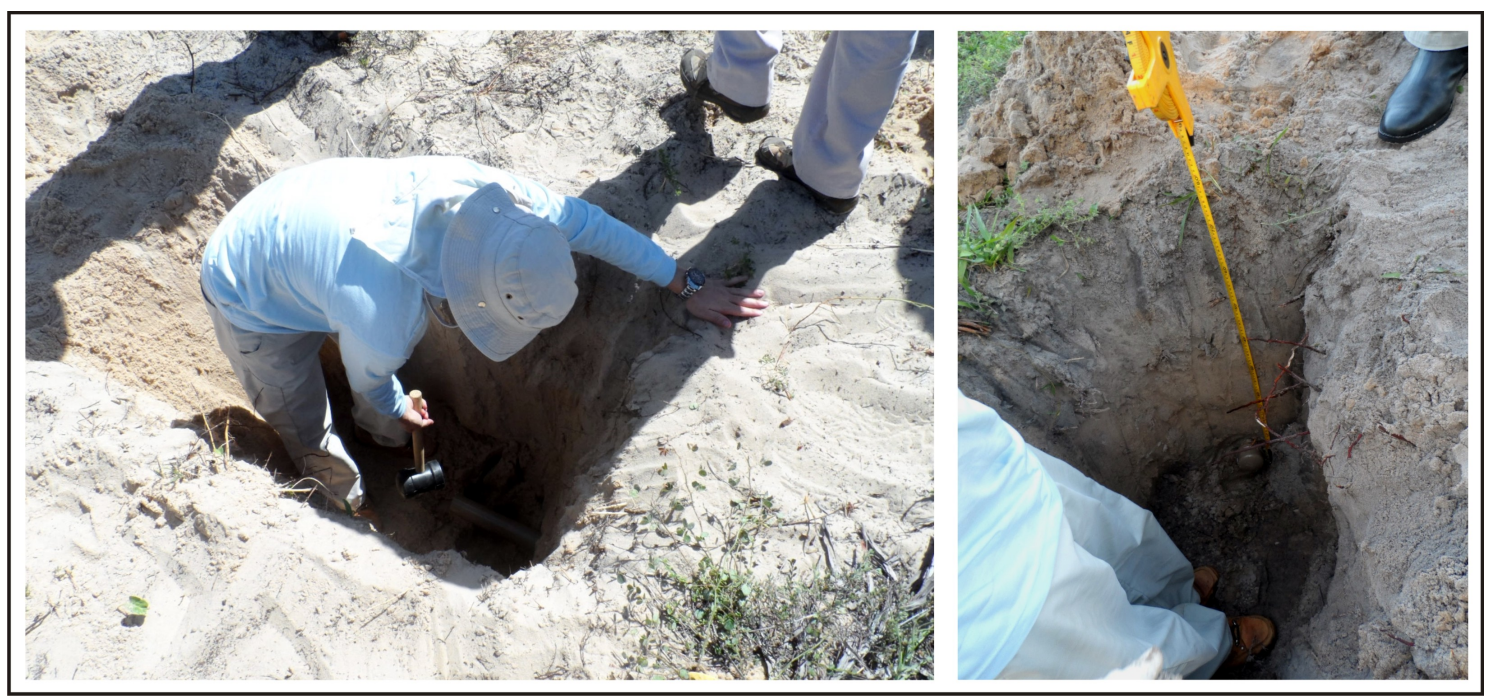

Figure 5 - Field sampling procedures for OSL dating.

\section{PSD ANALYSIS}

The particle size distribution was performed by the Soil Laboratory of the Faculty of Agricultural Engineering / State University of Campinas, using the pipette method (CAMARGO et al., 2009). The particle size classes found were very coarse sand $(2000 \mu \mathrm{m})$, coarse sand $(1000 \mu \mathrm{m})$, medium sand (500 $\mu \mathrm{m})$, fine sand $(250 \mu \mathrm{m})$, very fine sand $(125 \mu \mathrm{m})$, silt $(63 \mu \mathrm{m})$, and clay $(\leq 2 \mu \mathrm{m})$.

Using the laboratory results, a statistical analysis was performed employing the graphic method and the classification of the samples by textural group (FOLK and WARD, 1957) in Gradistat 6.0 (BLOTT and PYE, 2001). It is evident that statistical parameters such as sorting, skewness, and kurtosis are important to identify the sediment deposition environment, especially in areas with marine, fluvial and wind sedimentation processes.

\section{QUARTZ GRAIN MORPHOLOGICAL ANALYSIS}

A morphological analysis was carried out on the samples from the marine terraces to complement the statistical data obtained earlier, since the material may have been reworked by processes other than deposition time. This step was carried out at the Mineral Quantification Laboratory of the Institute of Geosciences - State University of Campinas, through the Scanning Electron Microscope (SEM).

The procedure involved the selection of 100 quartz grains from the medium sand fraction, which were metalized with carbon (Q150T metallizer) and digitally scanned with a scanning electron microscope (LEO 430i). Photomicrographs were performed on the zoom scales of $500 \mu \mathrm{m}, 200 \mu \mathrm{m}$, $100 \mu \mathrm{m}$, and $50 \mu \mathrm{m}$. The morphometry of the photomicrographs predominately indicated the properties of sphericity and roundness of the grains (KRUMBEIN, 1941; RITTENHOUSE, 1943). The surface texture of the quartz grains (ABD-ALLA, 1991) was analyzed to identify marks on the grains that indicate the type of process responsible for their deposition (GEORGIEV and STOFFERS, 1980; FRIHY and STANLEY, 1987).

\section{OSL DATING}

Absolute dating methods by luminescence have frequently been used in a variety of research on the Quaternary rather than radiocarbon methods, especially to reach older epochs, up to about 106. Among the various luminescence dating methods (for example, Thermoluminescence - TL and Infrared Stimulated Luminescence - IRSL), OSL has been widely applied to estimate the absolute age of marine deposits in different regions of the world and Brazil (BARRETO et al., 2002; ROSSETTI et al., 2011; ROSSETTI et al., 2015 and is widely considered an adequate technique for dating this type of material 
(JACOBS, 2008).

The samples were dated by the Laboratorio Dação, Comércio e Prestação de Serviços Ltda., whose detailed methodological protocol for preparing the material and obtaining the absolute ages can be consulted on the laboratory's website (DATAÇÃO, 2018). The material in the central part of the tubes was extracted in a red-light environment and underwent chemical treatments and the separation of quartz grains $(100-160 \mu \mathrm{m})$, which were free of organic matter and heavy metals to eliminate possible residual signs. A part of the material was subjected to solar radiation to decay the uranium (U), thorium $(\mathrm{Th})$ and potassium $(\mathrm{K})$ isotopes and subsequently, the calibration curve (MURRAY and ROBERTS, 1998) was obtained through samples that were irradiated with pre-defined doses (Gy).

The paleo dose values were obtained using the Single Aliquot Regenerative Dose - SAR protocol (MURRAY and WINTLE, 2000; WINTLE and MURRAY, 2006). Fifteen aliquots were applied to acquire the average value of equivalent doses (De). The accuracy of the mean De value and the standard deviation of the samples were verified (CLARKE, 1996; CLARKE, RENDEL, WINTLE, 1999) to identify possible flaws in the collection of the material.

\section{RESULTS}

\section{THE CHARACTERISTICS OF THE SURFACE DEPOSITS}

The particle size distribution by size class can be seen in Table 1 . In the samples from the higher terraces, fine sand $(\sim 43 \%)$ and very fine sand $(\sim 30 \%)$ predominated in both depths, with low percentages of silt and clay. In the lower terraces, medium sand and fine sand predominated at both depths and there were insignificant values of silt and clay. Fine and very fine sand occurred in the alluvial plain, in addition to significant silt and clay values. The textural group from the marine terrace samples was sandy with well selected to moderately selected sands, whereas the textural group of the river plain's superficial deposits varied between poorly selected sandy mud and muddy sand (figure 6).

\begin{tabular}{cccccccccc}
\hline & \multirow{2}{*}{$\begin{array}{c}\text { Depth } \\
\text { Sample }\end{array}$} & \multicolumn{6}{c}{ Grain size (\%) } & & \\
\cline { 3 - 8 } & (cm) & \multicolumn{6}{c}{ Sand } & Silt & Clay \\
\cline { 3 - 8 } & & vc & c & m & f & vf & Total & & \\
\hline P1A & 20 & 0,0 & 0,3 & 73,4 & 25,3 & 0,1 & 99,1 & 0,7 & 0,2 \\
P1B & 80 & 0,0 & 1,1 & 82,7 & 15,7 & 0,0 & 99,5 & 0,2 & 0,3 \\
P2A & 20 & 0,0 & 1,1 & 54,0 & 41,0 & 1,4 & 97,5 & 0,2 & 1,3 \\
P2B & 80 & 0,0 & 3,7 & 53,9 & 40,4 & 1,4 & 99,4 & 0,1 & 0,5 \\
P3A & 20 & 0,0 & 1,0 & 22,3 & 42,6 & 29,0 & 94,9 & 0,7 & 1,8 \\
P3B & 80 & 0,0 & 1,2 & 19,9 & 42,8 & 31,9 & 95,8 & 0,7 & 0,5 \\
P3.1A & 20 & 0,0 & 1,8 & 22,6 & 44,8 & 28,9 & 96,0 & 0,7 & 1,2 \\
P3.1B & 80 & 0,0 & 1,2 & 20,3 & 44,9 & 31,6 & 98,0 & 0,6 & 1,4 \\
P4A & 15 & 0,0 & 0,5 & 1,0 & 10,2 & 38,2 & 49,4 & 29,9 & 20,7 \\
P4B & 35 & 0,4 & 2,7 & 16,1 & 54,5 & 18,3 & 92,0 & 4,2 & 3,8 \\
P4C & 70 & 0,0 & 4,4 & 10,3 & 8,4 & 13,2 & 36,8 & 29,9 & 33,3 \\
P4.1A & 10 & 0,0 & 0,9 & 8,8 & 34,2 & 28,1 & 72,0 & 16,4 & 11,6 \\
P4.1B & 55 & 1,7 & 8,0 & 18,5 & 12,6 & 10,8 & 51,6 & 24,0 & 24,4 \\
\hline
\end{tabular}

Table 1 - Granulometric distribution of sediments sampled on the Itapicuru coastal plain. Holocene marine terraces (P1 and P2), Pleistocene marine terraces (P3 and P3.1) and floodplain (P4 and P4.1). 


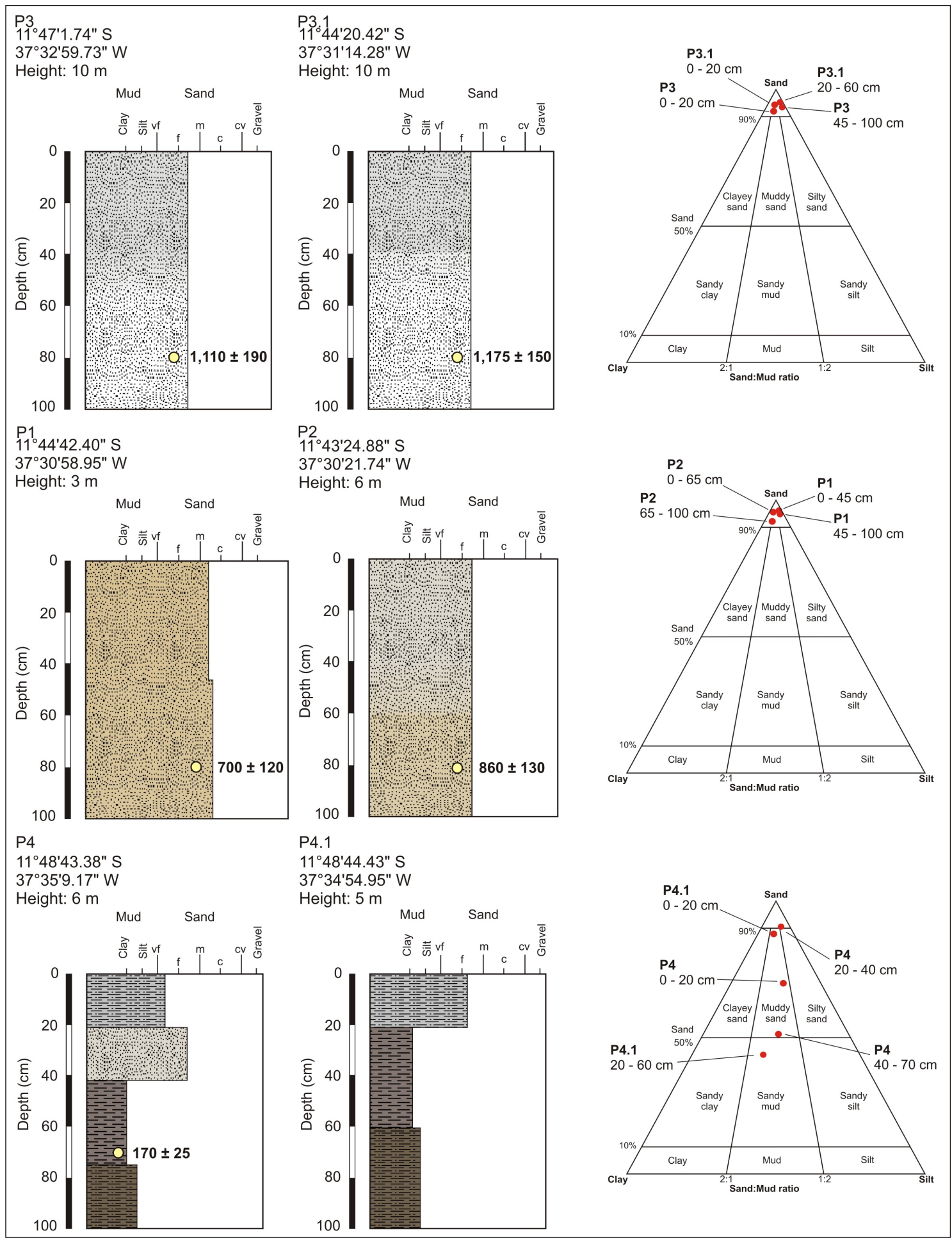

Figure 6 - Descriptive profiles of surface deposits and Folk diagram with the distribution of samples by textural class.

\section{MORPHOLOGY OF QUARTZ GRAINS FROM MARINE TERRACES}

The samples from the marine terraces were composed of well-selected sands, with a predominance of the spherical and asymmetric morphological patterns typical of beach sands (Table 2). The quartz grains' mechanical and chemical features (figure 7) indicated a depositional marine environment reworked by the wind in tropical climatic conditions. 


\begin{tabular}{cccc}
\hline Sample & Selection & Sphericity & Rounding \\
\hline P1A & Medium sand well-selected & Medium & Sub-rounded / rounded \\
P1B & Medium sand well-selected & Medium & Rounded \\
P2A & Medium sand moderately well selected & Medium & Sub-rounded / rounded \\
P2B & Medium sand moderately well selected & Medium & Sub-rounded \\
P3A & Fine sand moderately selected & Medium & Sub-rounded \\
P3B & Fine sand moderately selected & Medium & Rounded \\
P3.1A & Fine sand moderately selected & Medium & Sub-rounded \\
P3.1B & Fine sand moderately selected & Medium & Rounded \\
\hline
\end{tabular}

Table 2 - Morphological characteristics of Holocene marine terraces (P1 and P2) and Pleistocene marine terraces (P3 and P3.1).
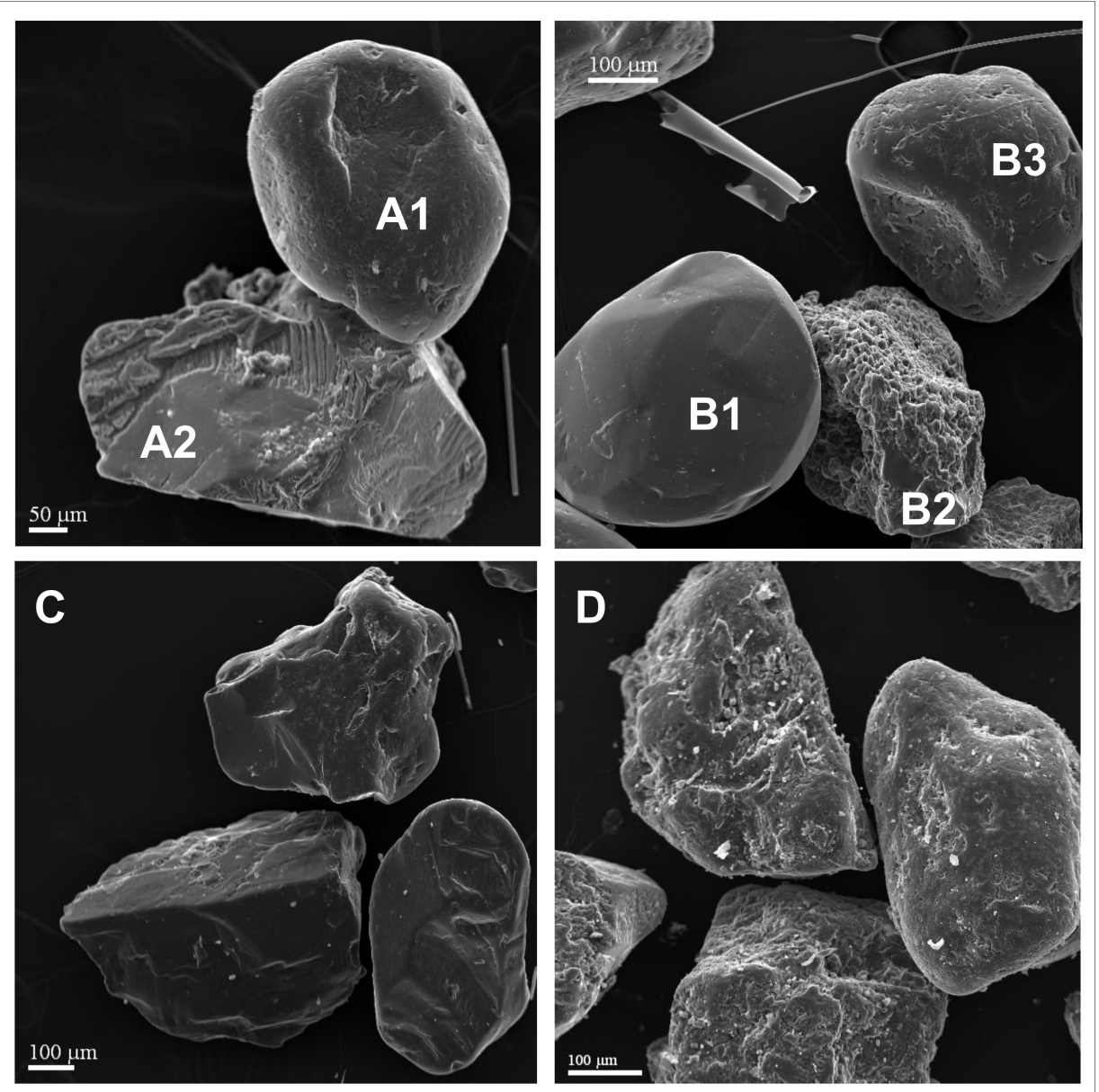

Figure 7 - Photomicrographs of surface features in quartz grains from marine terraces: Holocene marine terraces (A, B and C) and Pleistocene marine terraces (D).

The photomicrographs (figure 7) show rounded quartz grains with superficial depressions produced by chemical impregnation (A1 and B3) and sub-rounded features with medium sphericity, which were shaped by chemical impregnation and silica precipitation (D), in a medium to low-energy 
beach environment.

In A2, the grains showed breakage due to wind action with conchoidal fractures, striations with deep grooves and silica precipitation, reworked in a high-energy beach environment. In $\mathrm{C}$, the quartz grains were broken in a wind environment and had conchoidal fractures, cleavage blocks, and V-shaped forms. They were later transported and deposited in a beach environment.

In B1 the grain had a well-rounded shape with a polished surface and small conchoidal fractures and circular depressions, typical of a wind environment. In B2, the quartz grain had a rounded shape with a V-shaped chemical dissolution surface.

\section{OSL AGES}

The absolute OSL dating pointed to ages between 170 and 1,175 years (Tables 3 and 4), assuming that the surface material of the marine terraces and the river plain was last radiated during the Upper Holocene. The sequence of the higher terraces (level I) to the lower (terrace II) and the river plain, showed a decreasing age pattern, considering the margin of error of the samples. Thus, it is clear that the ages obtained showed a chronological coherence with marine regression events. The samples indicated a low degree of dispersion of equivalent doses by a single rate, resulting in a standard deviation with values below 5 Gy (Table 3), close to the average value of the De. These values demonstrated the absence of a residual sign, which allows us to affirm that they are reliable samples.

\begin{tabular}{ccccccc}
\hline Sample & $\begin{array}{c}\text { Height } \\
(\mathbf{m})\end{array}$ & $\begin{array}{c}\text { Depth } \\
(\mathbf{c m})\end{array}$ & $\begin{array}{c}\text { Total dose } \\
(\boldsymbol{\mu G y} / \mathbf{y r})\end{array}$ & $\begin{array}{c}\text { P } \\
(\mathbf{G y})\end{array}$ & $\begin{array}{c}\text { Standard } \\
\text { deviation }\end{array}$ & Age (yr BP) \\
\hline P1 & 3 & 80 & $720 \pm 85$ & 0.5 & 0.5 & $700 \pm 120$ \\
P2 & 6 & 80 & $465 \pm 50$ & 0.4 & 0.4 & $860 \pm 130$ \\
P3 & 10 & 80 & $1,355 \pm 163$ & 1.5 & 0.15 & $1,110 \pm 190$ \\
P3.1 & 10 & 80 & $3,260 \pm 250$ & 3.8 & 0.3 & $1,175 \pm 150$ \\
P4 & 6 & 70 & $3,560 \pm 310$ & 0.6 & 0.3 & $170 \pm 25$ \\
\hline
\end{tabular}

Table 3 - Absolute ages of levels of marine terrace and floodplain.

\begin{tabular}{ccccc}
\hline Sample & Th $(\mathbf{p p m})$ & $\mathbf{U}(\mathbf{p p m})$ & $\mathbf{K}(\boldsymbol{\%})$ & Water $(\boldsymbol{\%})$ \\
\hline P1 & $1.499 \pm 0.054$ & $0.443 \pm 0.136$ & $0.303 \pm 0.044$ & 12.2 \\
P2 & $1.393 \pm 0.070$ & $0.380 \pm 0.142$ & $0.034 \pm 0.005$ & 12.6 \\
P3 & $4.062 \pm 0.146$ & $1.075 \pm 0.256$ & $0.578 \pm 0.084$ & 5.0 \\
P3.1 & $15.728 \pm 0.566$ & $4.050 \pm 0.283$ & $0.905 \pm 0.131$ & 7.0 \\
P4 & $10.911 \pm 0.393$ & $2.797 \pm 0.015$ & $1.877 \pm 0.272$ & 10.3 \\
\hline
\end{tabular}

Table 4 - Concentration of radioactive isotopes $232 \mathrm{Th}, 238 \mathrm{U}+235 \mathrm{U}, 40 \mathrm{~K}$, and humidity.

\section{DISCUSSION}

\section{THE LAST DEPOSITIONAL EVENTS ON THE MARINE \\ TERRACES AND FLOODPLAIN}

The events recorded in the superficial sediments are Holocene deposition phases called Oldest phase II, Oldest phase I and the Current phase. The Oldest phase II occurred between 1,200 - 1,100 years BP and was recorded on the higher marine terraces (P3 and P3.1), currently located at about 10 meters in altitude. This was a high-energy deposition environment with waves and coastal currents 
depositing moderately well-selected fine sands. Subsequent depositions occurred by marine processes, with possible influences of fluvial and/or wind processes.

The frequency curve of profile three for the depth of $0-45 \mathrm{~cm}$ showed positive asymmetric deformation, which could indicate the fluvial or wind origin of the sediments. However, the sample's degree of selection rectified its beach origin. Thus, it was considered that in addition to the waves and coastal currents, river discharge may also have influenced the deposition environment, justifying the positive asymmetry (DUANE, 1964; FRIEDMAN, 1967; MARTINS, 2003).

In Oldest Phase I the depositional environment was also high energy, with the action of waves and coastal currents. The average diameter of the sand grains and the degree of selection confirmed this fact, although the degree of selection of the $0-45 \mathrm{~cm}$ layer of profile 1 indicates the possible reworking of the material by the wind after 700 years, as stated by Martin et al. (1980). The frequency curves show deformation to the left, that is, negative asymmetric curves that also attest to the high-energy beach depositional environment (DUANE, 1964).

Kurtosis resulted in a platykurtic curve at $0-45 \mathrm{~cm}$ for profiles 1 and 2 and at a depth of $45-90 \mathrm{~cm}$ for profiles 3 and 3.1. In itself, the curve indicates possible fluvial deposition (FOLK, 1957), which would be usual as these terraces are associated with the river mouth. However, the insignificant silt content and the morphological characteristics and surface features of the quartz grains in the samples, allow us to infer that the deposition agents were waves and coastal currents (MARTINS, 2003). The mesokurtic curve at the depth of $0-45 \mathrm{~cm}$ of profiles 3 and 3.1 indicates that these sediments were reworked by wind action, however, the degree of selection verified by statistical and morphometric analysis substantiate that it was a beach environment.

The lowering of the local sea level favored the deepening of the Itapicuru river and its tributaries, in line with the dissection of the higher terraces and the creation of first and second-order drainage channels between the terrace fragments. Samples P4 and P4.1 indicate the predominance of fluvial deposition processes in the last 170 years, known as the Current Phase, because it is the most similar to contemporary climatic conditions. The sedimentation rate presented by Farias (2014) confirms the current deposition conditions of the Itapicuru River and its tributaries in the wet climatic phase.

\section{EVOLUTION OF THE COASTAL PLAIN}

Correlations between the data obtained in this research and other local paleoenvironmental indicators (SANTANA, 2007; COSTA JUNIOR, 2008), enabled the organization of the evolutionary scenario of the Itapicuru coastal plain from Esquivel's Stage V (2006) in the period covering the Pleistocene-Holocene transition and the Upper Holocene (figure 8). 


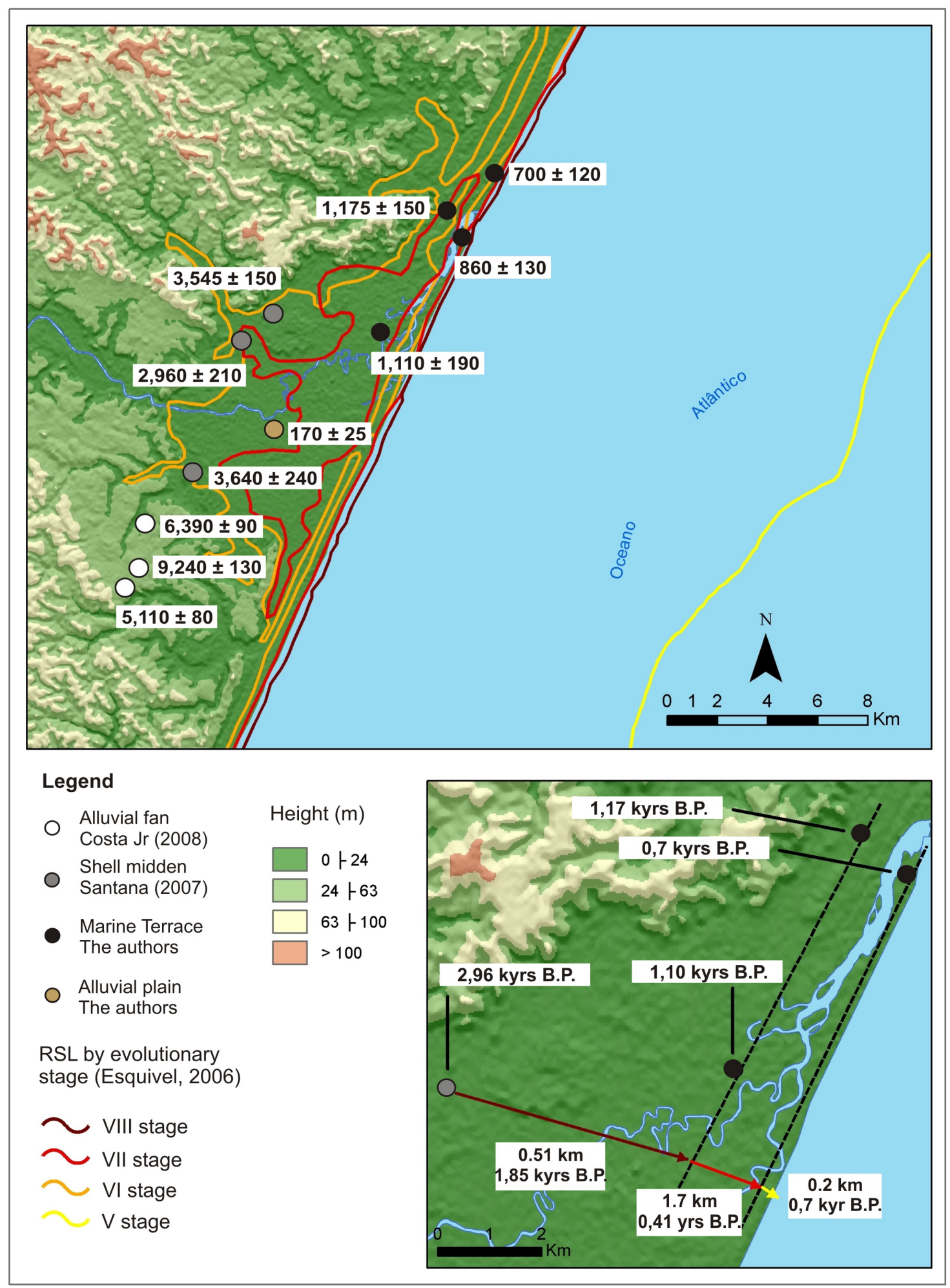

Figure 8 - Evolutionary picture of the Itapicuru coastal plain between the Pleistocene-Holocene and the Upper Holocene.

Approximately 16,000 years ago, the local sea level regressed about 120 meters below the current MSL during the glacial peak or stage V (ESQUIVEL, 2006). Due to arid climatic conditions, alluvial fans formed between the tablelands and the coastal plain (COSTA JUNIOR, 2008). These conditions lasted until approximately 5,500 - 5,100 years when the last marine transgression that marked stage VI occurred. 
After this, there was a slow, gradual process of marine regression that favored the formation of a lagoon during stage VII (ESQUIVEL, 2006) and the settlements of the groups of fishermen who built the shell middens (SANTANA, 2007). This regression lasted until approximately 2,900 when the last shell midden was abandoned (SANTANA, 2007). Stage VIII began after 2,500, the reduction of the MSL continued slowly and gradually until it reached a level similar to the present one (DOMINGUEZ, BITTENCOURT, MARTIN, 1981; ESQUIVEL, 2006).

Martin et al. (1980) and Esquivel (2006) affirmed that the deposits of level I marine terraces were formed in the Pleistocene, during stage V, whereas the deposits of level II terraces developed during the Holocene (stage VIII). However, the samples in P3 and P3.1 indicated marine deposition occurring around 1,100 on higher terraces, indicating a more recent depositional phase (Oldest Phase II). After the Oldest Phase II, the MSL fell rapidly to about 4 meters by 800 - 700 years in the Oldest Phase I and steadily continued to the local sea level.

The data presented in this research suggest that there was a rupture in the slow and gradual pace of local marine regression after 1,200 years, in contrast to previous research findings (MARTIN et al., 1980; DOMINGUEZ, BITTENCOURT, MARTIN, 1981; ESQUIVEL, 2006). This may suggest that neotectonic action in the study area (DANTAS and LIMA, 2008; LIMA, 2010) is a variable that had not been hitherto considered in the process of evolution of the Itapicuru coastal plain during the Holocene.

\section{REGIONAL CORRELATIONS}

The northern stretch of the coast of Bahia is relatively lithologically and climatically homogenous, allowing correlations to be made between the data obtained in this research and the fluctuations curve of the mean sea level to the north of Salvador (GONCALVES, 2016). The correlation with the curve shown in figure 9 was selected rather than the one elaborated by Martin et al. (1979) because of its similarity to the behavior of the MSL observed in the Itapicuru coastal plain.

When reevaluating the behavior of the curve in the last 8,000 years, Gonçalves (2016) demonstrated that the MSL was relatively stable and regressed smoothly to about 2.6 meters in altitude between 4,000 and 800 years BP along this stretch of the coast. After 800 years, the drop occurred abruptly, about 3 meters, until it reached the current average level. Although the causes of the sudden change in the curve were not given, the author suggests the possibility of regional neotectonic events. This proposition breaks with the classic interpretations of the evolution of Brazilian coastal plains, which only consider the action of eustatic and climatic factors. Nevertheless, it points to neotectonic action, as has already been proven by Lima et al. (2014) for the coastal plain of the São Francisco River.

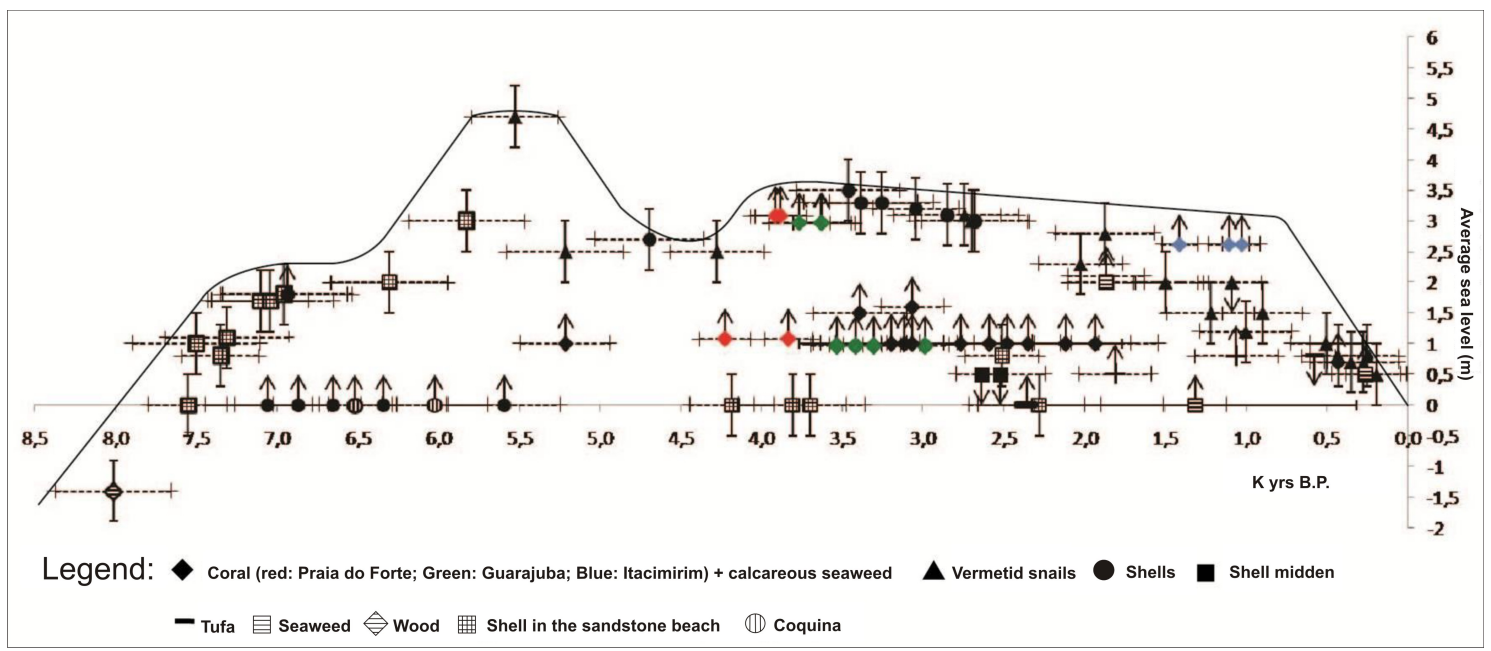

Figure 9 - Mean sea level (MSL) fluctuation curve for the last 8,000 years for the region of Salvador. Source: Gonçalves (2016, p. 27). 


\section{CONCLUSIONS}

Knowledge of the deposition phases after 1,100 has contributed to new interpretations regarding the pace of local marine regression and the triggering of geomorphological processes on a recent time scale. Even so, new data from absolute dating in terrace levels and other forms of relief are required, as well as surveys of new related neotectonic data to enrich and deepen the discussions in this field of study.

It is reasonable to hypothesize that the sudden change in the pace of local regression, which has also been identified elsewhere on the northern coast of Bahia, was driven by neotectonic events that affected this stretch of the coastline. It is also possible that the formation of frontal dunes on level II terraces after the years 700 is related to the reworking of surface coverings by wind action, associated with the strength, duration and incidence of SE trade winds, together with the lateral transport of sand along the seaboard.

Former interpretations considered that slow and gradual marine regressions, triggered by climatic alternations and eustatic oscillations, in a passive continental margin, were solely responsible for the origin and development of the Brazilian coastal plains. However, the data presented in this research contributes to a new interpretation of the geomorphological evolution of other Brazilian coastal plains where additional variables may be responsible for their genesis and evolution.

\section{ACKNOWLEDGMENTS}

The authors are grateful to the National Council for Scientific and Technological Development of Brazil - CNPq (process 408333 / 2013-8) and the São Paulo State Research Support Foundation - Brazil (process 2012 / 00145-6) for funding this research. We also thank Dr. Carlos César Uchoa de Lima, for his generosity in granting the images used in figure $3(b, c$, and $d)$

\section{REFERENCES}

ABD-ALLA, M.A.A. Surface textures of quartz grains from recent sedimentary environments along the Mediterranean coast, Egypt. Journal of African Earth Sciences, 13, 3-4, p. 367-375, 1991.

BARRETO, A.M. F.; BEZERRA, F.H.R.; SUGUIO, K.; TATUMI, S.H.; YEE, M.; PAIVA, R.P.; MUNITA, C.S. Late Pleistocene marine terrace deposits in northeastern Brazil: sea-level change and tectonic implications. Palaeogeography, Palaeoclimatology, Palaeoecology, 179, p. 57-69, 2002.

BITTENCOURT, A.C.S.P.; MARTIN, L.; VILAS BOAS, G.S.; FLEXOR, J.M. Quaternary marine formations of the coast of the state of Bahia (Brazil). In: SUGUIO, K.; FAIRCHILD, T.R.; MARTIN, L.; FLEXOR, J.M. (Ed.). Proceedings of the 1978 International Symposium on Coastal Evolution in the Quaternary. São Paulo: [s.n.], 1979. p. 232-253.

BLOTT, S. J.; PYE, K. Gradistat: a grain size distribution and statistics package for the analysis of unconsolidated sediments. Earth Surface Processes and Landforms, 26, p. 1237-1248, 2001.

CAMARGO, O.A.; MONIZ, A.C.; JORGE, J.A.; VALADARES, J.M. Métodos de análise química, mineralógica e física de solos do Instituto Agronômico de Campinas. Campinas: Instituto Agronômico de Campinas, 1986. 94 p.

CANTALAMESSA, G.; DI CELMA, C. Origin and chronology of Pleistocene marine terraces of Isla de la Plata and of flat, gently dipping surfaces of the southern coast of Cabo San Lorenzo (Manabi', Ecuador). Journal of South American Earth Sciences, 16, p. 633-648, 2004.

CLARKE, M.L. IRSL dating of sands: bleaching characteristics at deposition inferred from the use of single aliquots. Radiation Measurements, 26, p. 611-620, 1996.

CLARKE, M.L.; RENDELL, H.M.; WINTLE, A.G. Quality assurance in luminescence dating. Geomorphology, 29, p. 173-185, 1999. 
CORDIER, S.; FRECHEN, M.; HARMAND, D. The pleistocene fluvial deposits of the moselle and middle rhine valleys: new correlations and compared evolutions. Quaternaire, v. 20, n. 1, p. 35-47, 2009.

CORDIER, S. Optically stimulated luminescence dating: procedures and applications to geomorphological research in France. Géomorphologie, n.1, p. 21-40, 2010.

COSTA JÚNIOR, M. P. Interações morfo-pedogenéticas nos sedimentos do grupo barreiras e nos leques aluviais pleistocênicos no litoral norte do Estado da Bahia - município de Conde. 2008. 246 p. Tese (Doutorado em Geologia) - Instituto de Geociências, Universidade Federal da Bahia, Salvador, 2008.

DANTAS, J.J.R.; LIMA, C.C.U. As juntas tectônicas e a evolução das encostas no extremo norte do litoral da Bahia, Brasil. In: Simpósio Nacional de Geomorfologia. Anais... Belo Horizonte: UFMG, 2008. p. 1-8.

DATAÇÃO Comércio \& Prestação de Serviços LTDa. Metodologia de análise. São Paulo, 2018. Disponível em: . Acesso em: 03 de maio de 2018.

DOMINGUEZ, J. M. L.; BITTENCOURT, A.C.S.; MARTIN, L. Esquema evolutivo da sedimentação quaternária das feições deltaicas dos rios São Francisco (SE/AL), Jequitinhonha (BA), Doce (ES) e Paraíba do Sul (RJ). Revista Brasileira de Geociências, v. 11, n.4, p. 227-237, 1981.

DUANE, D. B. Significance of skewness in recent sediments, Western Pamlico Sound, North Carolina. Journal of Sedimentary Petrology, v. 34, p. 864-874, 1964.

ESQUIVEL, M.S. O Quaternário costeiro do município de Conde: implicações para a gestão ambiental. 2006. 103 p. Dissertação (Mestrado em Geologia) - Instituto de Geociências, Universidade Federal da Bahia, Salvador, 2006.

FARIAS, F. F. Condições de sedimentação e preenchimento dos estuários Itapicuru e Real, litoral norte do Estado da Bahia, Brasil. 2014. 123 p. Tese (Doutorado em Geologia) - Instituto de Geociências, Universidade Federal da Bahia, Salvador, 2014.

FOLK, R.L.; WARD, W.C. Brazos River bar: a study in the significance of grain size parameters. Journal of Sedimentary Petrology, 27, p. 3-26, 1957.

FRIEDMAN, G. M. Distinction between dune, beach, and river sands from their textural characteristics. Journal of Sedimentary Petrology, v. 31, p. 514-529, 1961.

FRIEDMAN, G. M. Dynamic processes and statistical parameters compared for size frequency distribution of beach and river sands. Journal of Sedimentary Petrology, v. 37, p. 327-354, 1967.

FRIHY, O.E.; STANLEY, D.J. Quartz grain surface textures and depositional interpretations, Nile delta region, Egypt. Marine Geology, 77, p. 247-255, 1987.

GEORGIEV, V.M.; STOFFERS, P. Surface textures of quartz grains from late Pleistocene to Holocene sediments of the Persian gulf/gulf of Oman - an application of the scanning electron microscope. Marine Geology, 36, p. 85-96, 1980.

GONÇALVES, P.M. Contribuição aos registros do nível do mar e ambientais do Holoceno no litoral norte da Bahia. 2016. 142 p. Tese (Doutorado em Geologia) - Instituto de Geociências, Universidade Federal da Bahia, Salvador, 2016.

INSTITUTO BRASILEIRO DE GEOGRAFIA E ESTATISTICA (IBGE). Manual Técnico de Geomorfologia. Rio de Janeiro: IBGE, Coordenação de Recursos Naturais e Estudos Ambientais. 2. ed., 2009.

INSTITUTO BRASILEIRO DE GEOGRAFIA E ESTATISTICA (IBGE). Atlas geográfico das zonas costeiras e oceânicas do Brasil. Rio de Janeiro: IBGE, Diretoria de Geociências, 2011. Disponível em: . Acesso em: 01 de setembro de 2019.

JACOBS, Z. Luminescence chronologies for coastal and marine sediments. Boreas, v. 37, p. 508-535, 
2008.

KOSS, J.; ETHRIDGE, F.G.; SCHUMM, S.A. An experimental study of the effects of base-level change on fluvial, coastal plain and shelf systems. Journal of Sedimentary Research, v. 64, n. 2, p. 90-98, 1994.

KRUMBEIN, W.C. Measurement and geological significance of shape and roundness of sedimentary particles. Journal of Sedimentary Petrology, 11, p. 64-72, 1941.

LIMA, C.C.U. Evidências da ação tectônica nos sedimentos da formação Barreiras presentes no litoral de Sergipe e ao norte da Bahia. Revista de Geografia, v. 27, n.1, p. 140-151, 2010.

LIMA, K.C.; CUNHA, C.M.L.; PEREZ FILHO, A. Dificuldades e possibilidades da cartografia geomorfológica no semiárido brasileiro. Revista Brasileira de Cartografia, v. 65, n. 6, p. 1063-1073, 2013.

MARTIN, L.; BITTENCOURT, A.C.S.P; VILAS BOAS, G.S.; FLEXOR, J.M. Mapa geológico do quaternário costeiro do estado da Bahia - 1:250.000: texto explicativo. Salvador: Secretaria das Minas e Energia/coordenação da produção mineral, 1980.

MARTINS, L.R. Recent sediments and grain size analysis. Revista Gravel, 1, p. 90-105, 2003.

MURRAY, A.S.; ROBERTS, R.G. Determining the burial of single grains of quartz using optical dating. Earth and Planetary Science Letters, 152, p. 163-180, 1998.

MURRAY, A.S.; WINTLE, A.G. Luminescence dating of quartz using an improved single-aliquot regenerative-dose protocol. Radiations Measurements, 32, p. 57-73, 2000.

PIRAZZOLI, P.A. Marine Terraces. In: SCHWARTZ, M.L. (Ed.) Encyclopedia of Coastal Science. Dordrecht: Springer, 2005, p. 632-633.

RITTENHOUSE G. A. visual method of estimating two-dimensional sphericity. Journal of Sedimentary Petrology, 13, p. 79-81, 1943.

ROSSETTI, D.F.; BEZERRA, F.H.R.; GÓES, A.M.; VALERIANO, M.M.; ANDRADES-FILHO, C.O.; MITTANI, J.C.R.; TATUMI, S.M.; BRITO-NEVES, B.B. Late Quaternary sedimentation in the Paraíba Basin, Northeastern Brazil: Landform, sea level and tectonics in Eastern South America passive margin. Palaeogeography, Palaeoclimatology, Palaeoecology, 300, p.191-204, 2011.

ROSSETTI, D.F.; POLIZEL, S.P.; COHEN, M.C.L.; PESSENDA, L.C.R. Late-Pleistocene-Holocene evolution of the Doce River delta, southeastern Brazil: implications for the understanding of wave-influenced deltas. Marine Geology, 367, p. 171-190, 2015.

SANTANA, C.C.S. Sambaquis perilagunares da zona costeira de Conde, Bahia. 2007. 172 p. Tese (Doutorado em Geologia) - Instituto de Geociências, Universidade Federal da Bahia, Salvador, 2007.

SILVEIRA, J.D. Morfologia do litoral. In: AZEVEDO, A. (Ed.) Brasil: a terra e o homem. São Paulo: Cia. Editora Nacional, 1964, p. 253-305.

SOUZA, T. A.; OLIVEIRA, R. C. Avaliação da potencialidade de imagens tridimensionais em meio digital para o mapeamento geomorfológico. Revista Geonorte, edição especial, v. 2, n. 4, p. 1348 $1355,2012$.

STORANI, D.L.; PEREZ FILHO, A. Novas Informações Sobre Geocronologia na Planície de Inundação do Rio Mogi Guaçu, SP, Brasil. Revista Brasileira de Geomorfologia, v. 16, 2, p. 191-199, 2015.

SUGUIO, K.; BEZERRA, F.H.R.; BARRETO, A.M.F. Luminescence dated Late Pleistocene wave-built terraces in northeastern Brazil. In: Annals of the Brazilian Academy of Sciences, 83, p. 907-920, 2011.

SUPERINTENDÊNCIA DE ESTUDOS ECONÔMICOS E SOCIAIS DA BAHIA (SEI). Balanço hídrico do estado da Bahia. Salvador: SEI, 1999. 
VILAS BOAS, G.S.; SAMPAIO, F.J.; PEREIRA, A.M.S. The Barreiras Group in the northeastern coast of the State of Bahia, Brazil: depositional mechanisms and processes. Annals of the Brazilian Academy of Sciences, v. 73, n. 3, 2001, p. 417-427.

WINTLE, A. G.; MURRAY, A. S.; A review of quartz optically stimulated luminescence characteristics and their relevance in single-aliquot regeneration dating protocols. Rations Measurements, 41, p. 369-391, 2006. 